\title{
Cost-Related Medication Nonadherence After Implementation of Medicare Part D, 2006-2007
}

\section{Citation}

Madden, Jeanne M., Amy J. Graves, Dennis Ross-Degnan, Becky A. Briesacher, and Stephen B. Soumerai. "Cost-related medication nonadherence after implementation of Medicare Part D, 2006-2007." JAMA: the journal of the American Medical Association 302, no. 16 (2009): 1755.

\section{Published Version}

doi:10.1001/jama.2009.1516

\section{Permanent link}

http://nrs.harvard.edu/urn-3:HUL.InstRepos:32696166

\section{Terms of Use}

This article was downloaded from Harvard University's DASH repository, and is made available under the terms and conditions applicable to Other Posted Material, as set forth at http:// nrs.harvard.edu/urn-3:HUL.InstRepos:dash.current.terms-of-use\#LAA

\section{Share Your Story}

The Harvard community has made this article openly available.

Please share how this access benefits you. Submit a story.

\section{Accessibility}


While these hypotheses about evolution may be impossible to prove, they may serve as sources of ideas for future experiments.

Jesse Roth, MD

jesserothmd@hotmail.com

Feinstein Institute for Medical Research

North Shore-Long Island Jewish Health System

Manhasset, New York

Financial Disclosures: None reported.

1. Leung CC, Lam TH, Chan WM, et al. Lower risk of tuberculosis in obesity. Arch Intern Med. 2007;167(12):1297-1304.

2. Haas DW. Mycobacterium tuberculosis. In: Mandell GL, Bennett JE, Dolin R, eds. Mandell, Douglas, and Bennett's Principles and Practice of Infectious Diseases. 5th ed. Philadelphia, PA: Churchill Livingstone; 2000:2576-2607.

3. Liu A, McLaughlin T, Liu T, et al. Differential intra-abdominal adipose tissue profiling in obese, insulin-resistant women [published online August 27, 2009]. Obes Surg. doi:10.1007/s11695-009-9949-9.

4. Fain JN. Release of interleukins and other inflammatory cytokines by human adipose tissue is enhanced in obesity and primarily due to the nonfat cells. Vitam Horm. 2006:74:443-477.

5. Ferrante AW Jr. Obesity-induced inflammation: a metabolic dialogue in the language of inflammation. J Intern Med. 2007;262(4):408-414.

6. Carmona L, Gómez-Reino JJ, Rodriguez-Valverde V, et al; BIOBADASER Group. Effectiveness of recommendations to prevent reactivation of latent tuberculosis infection in patients treated with tumor necrosis factor antagonists. Arthritis Rheum 2005;52(6):1766-1772.

\section{RESEARCH LETTER}

\section{Cost-Related Medication Nonadherence After Implementation of Medicare Part D, 2006-2007}

To the Editor: High drug costs cause some elderly or disabled patients to take less medication than prescribed or forgo basic needs to pay for medicines. ${ }^{1-3}$ The 2006 Medicare Part $\mathrm{D}$ drug benefit was intended to increase economic access to medicines. ${ }^{4}$ Data from 2006 indicated modest nationwide decreases in cost-related medication nonadherence (CRN) and forgoing basic needs following Part D implementation, but no decline in high rates of CRN among the sickest beneficiaries. ${ }^{5}$ We analyzed more recent data to determine whether the reductions remained stable in 2007.

Methods. The Medicare Current Beneficiary Survey ${ }^{6}$ (MCBS) is conducted by the Centers for Medicare \& Medicaid Services to inform and evaluate health policies. In-person interviews collect data on health and medical care from a nationally representative, rotating panel of Medicare enrollees. All community-dwelling respondents from 2004 through 2007 were included ( $\mathrm{n}=14500$ [2004], 14701 [2005], 14732 [2006], and 14804 [2007]; 29023 unique respondents).

The fall MCBS interview includes questions regarding $\mathrm{CRN},{ }^{2,5}$ defined as ever (in the current year) skipping or taking smaller doses to make a medicine last longer or not filling a prescription because it was too expensive. Self-reports of ever spending less on food, heat, or other basic needs to afford medicine were also examined.

Prevalence rates of CRN and forgoing basic needs from 2004 to 2007 were calculated for the overall population and in 5 subgroups: elderly (aged $\geq 65$ years) vs nonelderly disabled (aged $<65$ years) respondents, each group categorized as 0 to 2 vs 3 or more morbidities. Odds ratios (ORs) were estimated for 2007 vs 2005 and 2007 vs 2006 using survey-weighted logistic regression models controlling for defined covariates (age group, sex, race, income, general health status, survey participation) and number of morbidities (0-2 vs 3 or more). ${ }^{5}$ All analyses used Stata version 10 (StataCorp, College Station, Texas), 2-sided tests, and statistical significance of $P<.05$. Respondents provided oral informed consent. The study was approved by the human subjects committee of Harvard Pilgrim Health Care.

Results. Unadjusted prevalence rates and the adjusted ORs estimating changes in CRN and forgoing basic needs are shown in the TABLE. Prevalences were consistently higher for nonelderly disabled vs elderly beneficiaries and for sicker vs healthier

Table. Prevalence Rates From 2004 to 2007 and Changes in Cost-Related Nonadherence and Forgoing Basic Needs Among Community-Dwelling Medicare Beneficiaries

\begin{tabular}{|c|c|c|c|c|c|c|c|c|c|}
\hline \multirow[b]{3}{*}{ Subgroup } & \multirow{3}{*}{$\begin{array}{c}\text { Observations, } \\
\text { No. }^{a}\end{array}$} & \multirow{2}{*}{\multicolumn{4}{|c|}{ Unadjusted Prevalence, $\%{ }^{\mathrm{b}}$}} & \multicolumn{2}{|c|}{2007 vs 2006} & \multicolumn{2}{|c|}{2007 vs 2005} \\
\hline & & & & & & \multirow{2}{*}{$\begin{array}{c}\text { Adjusted OR } \\
(95 \% \mathrm{Cl})^{\mathrm{b}}\end{array}$} & \multirow{2}{*}{$\begin{array}{c}P \\
\text { Value }\end{array}$} & \multirow{2}{*}{$\begin{array}{c}\text { Adjusted OR } \\
(95 \% \mathrm{Cl})^{\mathrm{b}}\end{array}$} & \multirow{2}{*}{$\begin{array}{c}P \\
\text { Value }\end{array}$} \\
\hline & & 2004 & 2005 & 2006 & 2007 & & & & \\
\hline \multicolumn{10}{|c|}{ Cost-Related Medication Nonadherence } \\
\hline Overall population & 58647 & 15.2 & 14.1 & 11.5 & 10.7 & $0.91(0.84-0.99)$ & .02 & $0.71(0.65-0.79)$ & $<.001$ \\
\hline Elderly, 0-2 morbidities ${ }^{c}$ & 23943 & 10.6 & 9.9 & 6.9 & 6.4 & $0.94(0.80-1.10)$ & .41 & $0.63(0.52-0.75)$ & $<.001$ \\
\hline Elderly, $\geq 3$ morbidities $^{c}$ & 23814 & 14.8 & 12.9 & 10.4 & 9.9 & $0.96(0.85-1.08)$ & .49 & $0.76(0.65-0.88)$ & $<.001$ \\
\hline${\text { Nonelderly disabled, } 0-2 \text { morbidities }^{c}}^{c}$ & 5301 & 21.5 & 24.5 & 19.3 & 19.4 & $0.98(0.74-1.30)$ & .91 & $0.74(0.57-0.95)$ & .02 \\
\hline 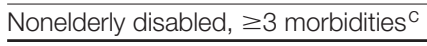 & 4723 & 35.4 & 33.4 & 34.0 & 28.0 & $0.74(0.60-0.92)$ & .01 & $0.77(0.60-0.995)$ & .046 \\
\hline \multicolumn{10}{|c|}{ Spent Less on Basic Needs } \\
\hline Overall population & 58457 & 10.6 & 11.1 & 7.6 & 7.8 & $1.03(0.92-1.15)$ & .61 & $0.66(0.59-0.74)$ & $<.001$ \\
\hline Elderly, 0-2 morbidities ${ }^{\mathrm{c}}$ & 23867 & 6.2 & 6.8 & 3.5 & 4.0 & $1.18(0.95-1.47)$ & .14 & $0.58(0.47-0.70)$ & $<.001$ \\
\hline Elderly, $\geq 3$ morbidities ${ }^{\mathrm{C}}$ & 23781 & 10.4 & 10.8 & 6.4 & 7.3 & $1.19(1.03-1.38)$ & .02 & $0.66(0.55-0.79)$ & $<.001$ \\
\hline 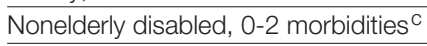 & 5274 & 16.7 & 19.3 & 14.2 & 13.9 & $0.96(0.68-1.36)$ & .82 & $0.69(0.51-0.93)$ & .02 \\
\hline 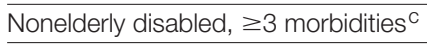 & 4717 & 29.5 & 28.4 & 27.9 & 23.3 & $0.78(0.61-0.99)$ & .04 & $0.76(0.59-0.98)$ & .04 \\
\hline \multicolumn{10}{|c|}{$\begin{array}{l}\text { Abbreviations: } \mathrm{Cl} \text {, confidence interval; OR, odds ratio. } \\
\text { a Numbers of observations vary with item response rates and availability of information on subgroup characteristics. } \\
\text { b Prevalence rates and adjusted ORs were estimated with survey weights to represent national populations of approximately } 37 \text { million to } 39 \text { million community-dwelling Medicare } \\
\text { beneficiaries per year during this period. } \\
{ }^{c} \text { Morbidity categories were described previously. }\end{array}$} \\
\hline
\end{tabular}


beneficiaries. Between 2006 and 2007, there was a very small but statistically significant decrease in CRN for the overall population; in the 4 subgroups, statistically significant decreases in CRN and forgoing basic needs occurred only for disabled beneficiaries with 3 or more morbidities. Compared with 2005, prior to Part D, the prevalences of CRN and forgoing basic needs in 2007 declined significantly for the overall population and for all 4 subgroups (ORs between 0.58 and 0.77 ; $P$ values $<.05$ ).

Comment. Changes in CRN represent a crucial intermediate step between expanded economic access and potential health improvements. Previously, modest statistically significant reductions were found in CRN and forgoing basic needs for Medicare beneficiaries following implementation of Part D in 2006, controlling for historical changes. More recent data confirm that these reductions were sustained in 2007. The very small 2006 to 2007 reduction in CRN for the overall population was similar to that estimated between 2004 and $2005,{ }^{5}$ prior to Part D. Study limitations include lack of utilization data, likely underestimation of CRN, and the possibility that contemporaneous phenomena could explain the changes observed. ${ }^{5}$

Subgroup analyses suggest that sicker disabled beneficiaries experienced lagged improvements, apparent only in 2007; such patients may require more time to adapt to administrative changes and realize benefits. Nevertheless, postPart D reductions in CRN were small in comparison with the persistent disparities in CRN associated with disability and multiple chronic conditions.

Jeanne M. Madden, PhD

jeanne_madden@hphc.org

Harvard Medical School

Boston, Massachusetts

Amy J. Graves, MPH

Harvard Pilgrim Health Care Institute

Boston

Dennis Ross-Degnan, ScD

Harvard Medical School

Becky A. Briesacher, PhD

University of Massachusetts Medical School

Worcester

Stephen B. Soumerai, ScD

Harvard Medical School
Author Contributions: Dr Madden had full access to all of the data in the study and takes responsibility for the integrity of the data and the accuracy of the data analysis.

Study concept and design: Madden, Ross-Degnan, Briesacher, Soumerai.

Acquisition of data: Madden, Soumerai.

Analysis and interpretation of data: Madden, Graves, Ross-Degnan, Briesacher, Soumerai.

Drafting of the manuscript: Madden

Critical revision of the manuscript for important intellectual content: Madden, Graves, Ross-Degnan, Briesacher, Soumerai.

Statistical analysis: Madden, Graves, Ross-Degnan, Briesacher, Soumerai.

Obtained funding: Madden, Ross-Degnan, Soumerai.

Administrative, technical, or material support: Madden, Graves.

Study supervision: Madden, Soumerai.

Financial Disclosures: Dr Madden reported receiving prior research support from AstraZeneca. Drs Ross-Degnan and Soumerai and Ms Graves reported receiving prior research support from Eli Lilly. Dr Briesacher reported receiving prior research support and consulting fees from Novartis.

Funding/Support: This study was supported by National Institute on Aging grants RO1AG028745 and RO1AG022362 and the Harvard Pilgrim Health Care Foundation. Drs Ross-Degnan, Briesacher, and Soumerai are investigators in the HMO Research Network Center for Education and Research in Therapeutics, supported by the US Agency for Healthcare Research and Quality (grant 2U18HS010391).

Role of the Sponsors: The funding organizations had no role in the design and conduct of the study; in the collection, analysis, and interpretation of the data; or in the preparation, review, or approval of the manuscript.

Additional Contributions: Fang Zhang, PhD (Harvard Medical School); Alyce S Adams, PhD (Kaiser Permanente Division of Research); Jerry H. Gurwitz, MD (University of Massachusetts Medical School); and Gerald S. Adler, MPhil (Centers for Medicare \& Medicaid Services [CMS]), also contributed to this research. Dana Gelb Safran, ScD (Tufts University School of Medicine), provided foundational work on CRN and prior collaborations. Franklin Eppig, JD, and Andrew Shatto (CMS) provided consistent support. Robert LeCates, MA (Harvard Pilgrim Health Care Institute), provided assistance during manuscript preparation. Drs Zhang, Adams, Gurwitz, and Safran and Mr LeCates received partial salary support from the NIA grants mentioned. Dr Eppig, Mr Adler, and Mr Shatto received no direct compensation.

1. Safran DG, Neuman P, Schoen $C$, et al. Prescription drug coverage and seniors: findings from a 2003 national survey. Health Aff (Millwood). 2005(suppl web exclusive):W5-152-W5-166

2. Soumerai SB, Pierre-Jacques $M$, Zhang F, et al. Cost-related medication nonadherence among elderly and disabled Medicare beneficiaries: a national survey 1 year before the Medicare drug benefit. Arch Intern Med. 2006;166(17):18291835.

3. Briesacher BA, Gurwitz JH, Soumerai SB. Patients at-risk for cost-related medication nonadherence: a review of the literature. J Gen Intern Med. 2007;22 (6):864-871

4. The Medicare Prescription Drug Benefit: The Henry J. Kaiser Family Foundation fact sheet [March 2009]. http://www.kff.org/medicare/upload/7044-09 pdf. Accessed April 21, 2009.

5. Madden JM, Graves AJ, Zhang F, et al. Cost-related medication nonadherence and spending on basic needs following implementation of Medicare Part D. JAMA. 2008;299(16):1922-1928.

6. Technical documentation for the Medicare Current Beneficiary Study [2002] Centers for Medicare \& Medicaid Services. Sourcebook Series: Health and Health Care of the Medicare Population. http://www.cms.hhs.gov/mcbs/downloads /HHC2002appendixA.pdf. Accessed April 21, 2009. 